\title{
EXERGETIC ANALYSIS OF BREAKFAST CEREAL PRODUCTION IN NIGERIA
}

\author{
M. A. Sulaiman ${ }^{1, *}$ S. I. Kuye ${ }^{2}$, S. O. Giwa ${ }^{3}$ and O. A. Olowoyeye ${ }^{4}$

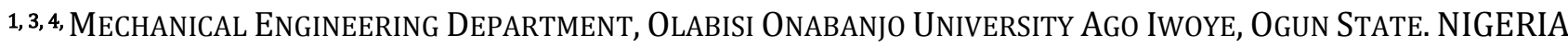

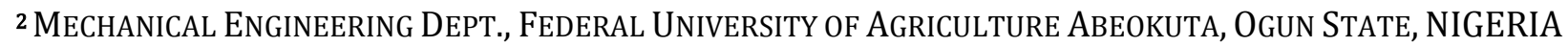 \\ Email addresses: ${ }^{1}$ sulaiman.adedoyin@oouagoiwoye.edu.ng, ${ }^{2}$ ibiyemikuye@yahoo.com, \\ 3 lanregiwa7@gmail.com, ${ }^{4}$ uphold901@gmail.com
}

\begin{abstract}
This work comprehensively studied energy and exergy analyses of breakfast cereal production in Nigeria. The process analysis method of energy accounting was used to evaluate the energy requirement for each of the five defined unit operations. The total energy used in the operation is 1,287.94 MJ. The types of energy used in breakfast cereal production were electrical, thermal and manual and the respective percentages are $48.87 \%, 50.53 \%$ and $0.60 \%$. It was estimated that an average energy intensity of $11.27 \mathrm{MJ} / \mathrm{kg}$ was required for the production of breakfast cereals. The most energy intensive operation was identified as the mixing operation followed by milling with energy intensities of $665.10 \mathrm{MJ} / \mathrm{kg}$ and $383.04 \mathrm{MJ} / \mathrm{kg}$, respectively. The exergy analysis revealed that the roller dryer was responsible for most of the inefficiency (over 65.94\%) followed by the wet mixer (27.40\%). Suggestions for energy saving which will help in the reducing the high expenditure on energy and thus improve the profit margin were provided.
\end{abstract}

Keywords : Energy, Exergy, Efficiency Breakfast Cereal

\section{INTRODUCTION}

Energy is the driving force required for any activity or process. It has become the major element of an economy and a factor that not only determines the growth but has also an indicator of the development of the economy. Energy which can be classified as renewable - solar, wind, hydroelectric, biomass, tidal and geothermal energy or non-renewable - fossil fuels and nuclear energy [1] is consumed by all the sectors of an economy. The industrial and residential sectors have the greatest consumption value of Nigeria's domestic energy [2]. Most production industries worldwide depend heavily on energy derived from non-renewable resources [3]. In the south-western Nigeria, gasoline consumption is highest in Lagos and Oyo states with 24,200,352 litres (59.3\%) and 6,260,901 litres (15.3\%), respectively, due to industrial processes [4]. The food industry is one of the energy-intensive industries.

In the food industry, energy is consumed to various degrees by different unit operations like handling, cleaning, sorting/grading, milling, mixing, pelletizing, drying, blanching, frying, cooking, pasteurizing, packaging, etc. Of all these operations, milling and

\footnotetext{
* Corresponding author, tel: + 234-803-863-4054
}

drying operations have been recognized to have high energy demand even as they are also least energyefficient [5, 6]. Energy consumption in food production/crop processing industry has been identified to be affected by factors like production scale; type of equipment; efficiency of machine; maintenance; automation; grain properties; size of screen holes for milling operations; speed of operation; feeding rate [6 11].

Presently, energy studies are not been limited to methods of consumption and transformation but also to the effectiveness of energy utilization, energy usage pattern and efficiency. Energy efficiency has attracted increasing attention in the food industry [6 - 10]; hence, researches have been geared towards identifying the causes of energy loss in different industrial production processes.

A robust way of identifying the amount and causes of energy lose in a production process is by thermodynamic analysis. A comprehensive thermodynamic analysis of system includes both energy and exergy analyses in order to obtain a more complete picture of system behaviour [12]. Energy analysis involves assessing and analysing the energy disposition of a system by investigating the energy (heat) transfer and/or transformation of energy by the 
completion of an energy balance equation [13]. Exergy analysis provides a much more accurate description of the thermodynamic performance of a system, and hence is better able to identify the best opportunities for resource minimization [3] and in accounting for the system's inefficiency in term of exergy destruction [14]. Exergy which is of four types - physical, chemical, potential and kinetic predicts the thermodynamic performance of an energy system and the efficiency of the system components by accurately quantifying the entropy-generation of the components [15]. Thermodynamic analysis of food production industries also results in the generation of mathematical models $[9-12,16]$ which helps in prediction, optimization and improvement. Regardless of the type of model and the system, the model must define the system boundaries and ensure the conservation of mass and energy [17]. Thermodynamic analysis has been successfully done for several non-food production industries $[12,14,15]$ and some food production/crop processing industries like; orange juice production [3], commercial banking industry [18], confectionery plant [19], cowpea milling [20], corn wet milling [21], flour Mill [22], soybean oil extraction [23], palm kennel oil extraction [16], etc. In breakfast cereal production, researchers have covered areas like water mobility characteristics [24], state transition and quality [25], energy requirements [26], etc. but, the thermodynamic analysis of a breakfast cereal production industry is scarce in literature.

It is therefore important to maintain an efficient energy usage in production of breakfast cereal which will bring about a reduction in the cost price of the breakfast cereal thereby ensuring its availability to the teeming working population. This can be done by performing an energy and exergy analysis of the production system. Based on this, this paper is aimed at carrying out energetic and exergetic analysis of a typical breakfast cereal (corn flakes) production process in Nigeria.

\section{METHODOLOGY}

\subsection{Plant Description}

Thermodynamic analysis was conducted on a breakfast cereal industry located in Lagos, Southwestern Nigeria. The energy requirement and exergy inefficiency for processing a batch of 30 tonnes of maize grain processed into 25 tonnes of flour was estimated. The plant occupied a 16 hectare plot and operates on a 3shift of morning and afternoon of 7- hours and night duty of 10 - hours per day. The sources of energy for the plant are electrical, thermal and manual. The primary source of electrical energy is the tri-generation plant which comprises of two generators producing 3.8
MW each of electricity totaling 7.6 MW. Steam generated from a gas-fueled steam boiler is used for heating purpose, while cooling is effected through an absorption chiller which is powered by the exhaust from the generating set to give the generator an estimated efficiency of $68 \%$.

\subsection{Process Description}

The production process is divided into five unit operations: (i) Intake process, (ii) Cleaning process (iii) Milling process (iv) Mixing process (v) Packaging process. The process flow chart for the production process is shown in Figure 1.

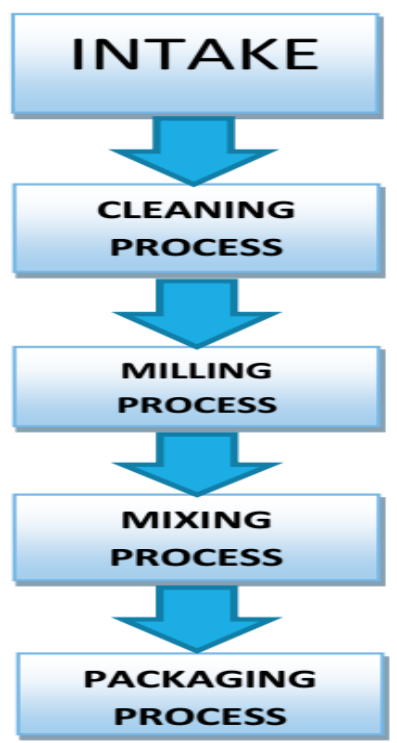

Fig 1: Flow diagram of maize milling

Intake: A bulk of maize is conveyed via trucks and tipped into a hopper either manually or automatically through the use of blowers, which sucks air from the atmosphere and use the sucked air to transport the maize upward into the storage bins or silos for storage. Two storage silos each having a capacity of 30 tons were in use.

Cleaning: Grains are first transported via a flow balancer where a magnetic trap is installed which traps any metal that might be attached to the grains. The grains then go into a separator where the hull, chaffs and husks not previously separated from the grains are removed. The grain passes through two sets of screens. Larger size foreign particles are kept by the first screen and directed to coarse offal discharge line. The remaining smaller size impurities or foreign particles, which pass through the second screen, are transferred to fine offal discharge line. The grains are further cleaned in a destoner which comprises pressure fans, gauges, vibrating deck, and two opening holes where

Vol. 37, No. 1, January 2018 
the impurities and clean seeds flow out, respectively into different bin.

Milling: Clean maize grains are dozed into the parallel working roller mills. There are three roller mills involved in the milling process so as to ensure that the maize is effectively milled into fine flour. The grinded product is discharged into a hopper, which is placed underneath the roller mill and then conveyed by means of a pneumatic system. The flour is thereafter transferred into a plan sifter which filters the fine flour and removes the grains that has not been converted into fine flour and recycled to the roller mills for it to be milled until it becomes fine flour.

Mixing: Flour and sugar are mixed at a set standard before they are transferred into a cyclone. The mixture is then moved into the dry mixer where other minor ingredients are effectively added before the drying. After drying, it is conveyed into a wet mixer where it is mixed with hot water at about $55^{\circ} \mathrm{C}$ and vitamin premix. Compressed air is now used to transport the product along a line where steam is injected at $135^{\circ} \mathrm{C}$ before the product is transferred to a Jumbo roller dryer. A blower then conveys the film properly with the use of star valve and deposits the flakes in the cyclone where it is evenly milled by a granulator before it is stored.

Packaging: The products are left for about 50 minutes to cool down before being tipped into a filling and sealing machine.

\subsection{Data Collected}

For the breakfast cereals production under study, the following data were collected:

i. Electricity; diesel and gas consumed by the generators per month for a 3-month period,

ii. Production rate of the company for a 3 -month period,

iii. Number of factory workers (shift) per day,

iv. Power rating of all machines/equipment powered by electricity.

\subsubsection{Energy Evaluation}

The electrical energy input

$$
E_{p}=\eta p t
$$

The electrical energy input $E_{P}$ in kWh was obtained by multiplying the rated power of the electrical motor, $p$ in $\mathrm{kW}$ with the corresponding hours of operation $\mathrm{t}$, the motor efficiency, $\eta$, is assumed to be $80 \%$ [27].

Manual energy input, in $\mathrm{kW}$ was estimated based on the maximum continuous energy consumption rate of 0.30 $\mathrm{kW}$ and conversion efficiency of $25 \%$. According to Odigboh [28], the physical power output of a normal human labour in the tropical climate is approximately $0.075 \mathrm{~kW}$ sustained for 8-10 hr. workday.

$$
E_{m}=0.75 N t
$$

Where $\mathrm{N}$ is the number of people involved and $\mathrm{t}$ is the time taken in hours.

The thermal energy input $E_{f}$ was calculated based on quantity of fuel used to generate steam in the boiler. The thermal energy is estimated by multiplying the quantity consumed by corresponding calorific value, $C_{f}$ of fuel which is gas [29].

$$
E_{f}=C_{f} W
$$

$E_{f}$ is the thermal energy input (J), $C_{f}$ is the calorific value of fuel $(\mathrm{J} / I)$ and $W$ is the quantity of fuel $(I)$ Note that the calorific value for natural gas is $43 \mathrm{MJ} / \mathrm{kg}$. For each unit operation the total energy input according to Ameri et al. [15] is given as:

$$
E_{t}=E_{p}+E_{f}+E_{m}
$$

\subsubsection{Exergy Model Equations}

Exergy $E_{x}$ for a closed system may be defined mathematically as Dincer and Cengel [13],

$$
E_{z}=v\left(p-p_{o}\right)-s\left(T-T_{o}\right)-\sum n_{i}\left(\mu_{i}-\mu_{i o}\right)
$$

The exergy of a flow crossing the system boundaries of an open system can be written as

$$
E_{x}=m\left(h-h_{o}\right)+T_{o}\left(S-S_{o}\right)
$$

Where $\mathrm{h}$ is the specific enthalpy $(\mathrm{kJ} / \mathrm{kg}), \mathrm{s}$ is the specific entropy $(\mathrm{kJ} / \mathrm{kg} \mathrm{K}), \mathrm{v}$ is volume, $\mathrm{T}$ is temperature, $\mathrm{P}$ is pressure of each process stream and $\mathrm{m}$ is the mass flow rate. Also, $\mu_{i}$ is the chemical potential of the substance i. The subscript "o" denotes the conditions of the reference environment. The net exergy changes of the process stream in and out of each unit operation in the breakfast cereal production system were evaluated using the predictive model proposed by Waheed, et al. [3] and Fadare et al., [27]:

$$
e_{2}-e_{1}=c_{p}\left(T_{2}-T_{1}\right)\left[1-\frac{T_{o}}{\left(T_{2}-T_{1}\right) m l}\right]
$$

Where $C_{p}$ is specific heat constant and

$$
\left(T_{2}-T_{1}\right) m l=\frac{T_{2}-T_{1}}{\operatorname{In}\left(T_{2} / T_{1}\right)}
$$

\subsubsection{Exergy Efficiency and the useful Work of the System}

The exergy efficiency can be evaluated with the expression

$$
\begin{aligned}
\Psi & =1-I_{f f} \\
I_{f f} & =\frac{I}{\sum I_{\text {all }}}
\end{aligned}
$$

where $I_{f f}$ is the inefficiency of the system and is defined as the ratio of the irreversibility in each unit operation to the irreversibility in the overall operations.

Vol. 37, No. 1, January 2018 
Table 1: Operating parameters for generators and boilers.

\begin{tabular}{lc}
\hline Parameters & Values \\
\hline Power factor (PF) & 0.8 \\
KVA & 4,320 \\
MW & 7.6 \\
Load during operation & $60-75 \%$ \\
Diesel usage $(\mathrm{l} / \mathrm{h})$ & 450 \\
Gas usage $(\mathrm{l} / \mathrm{h})$ & 523 \\
Boiler operating conditions & \\
Mass steam requirement $(\mathrm{kg} / \mathrm{h})$ & 17,240 \\
Gas usage $(\mathrm{l} / \mathrm{h})$ & 200 \\
Operating temperature $\left({ }^{\circ} \mathrm{C}\right)$ & 250 \\
Operating pressure $($ bar $)$ & 13.8 \\
\hline
\end{tabular}

Table 2: Required parameters for evaluating thermodynamic analysis of breakfast cereals production operation

\begin{tabular}{|c|c|c|}
\hline $\begin{array}{l}\text { Unit } \\
\text { operation }\end{array}$ & Required parameters & Value \\
\hline \multirow[t]{3}{*}{ Intake } & $\begin{array}{l}\text { Number of person involved } \\
\text { in intake }\end{array}$ & 1 \\
\hline & Time taken $(\mathrm{h})$ & 0.42 \\
\hline & Weight (kg) & 30,000 \\
\hline \multicolumn{3}{|l|}{ Cleaning } \\
\hline $\begin{array}{l}\text { Grain } \\
\text { separator }\end{array}$ & Electrical power $(\mathrm{kW})$ & 0.6 \\
\hline \multirow[t]{2}{*}{ Destoner } & Electrical power $(\mathrm{kW})$ & 0.6 \\
\hline & Time taken for cleaning (h) & 3 \\
\hline \multicolumn{3}{|l|}{ Milling } \\
\hline \multirow[t]{3}{*}{$1^{\text {st }}$ roller mill } & Electrical power $(\mathrm{kW})$ & 18.5 \\
\hline & Weight (kg) & 15,000 \\
\hline & Time taken $(\mathrm{h})$ & 4 \\
\hline \multirow[t]{3}{*}{$2^{\text {nd }}$ roller mill } & Electrical power $(\mathrm{kW})$ & 18.5 \\
\hline & Weight fraction (kg) & 15,000 \\
\hline & Time taken(h) & 2 \\
\hline \multirow[t]{2}{*}{ Plan sifter } & Electrical power $(\mathrm{kW})$ & 11 \\
\hline & Time taken(h) & 2 \\
\hline \multicolumn{3}{|l|}{ Mixing } \\
\hline \multirow[t]{3}{*}{ Dry mixer } & Electrical power $(\mathrm{kW})$ & 11 \\
\hline & Time taken(h) & 0.25 \\
\hline & Weight of flour (kg) & 10,000 \\
\hline \multirow[t]{5}{*}{ Wet mixer } & Electrical power $(\mathrm{kW})$ & 22 \\
\hline & Time taken $(\mathrm{h})$ & 0.1 \\
\hline & Volume of water (l) & 130,000 \\
\hline & Temp. of water (K) & 328 \\
\hline & Steam inlet temp $(\mathrm{K})$ & 408 \\
\hline \multirow[t]{3}{*}{ Roller dryer } & Electrical power $(\mathrm{kW})$ & 22 \\
\hline & Compressed air (bar) & 13 \\
\hline & Time taken for drying (h) & 3 \\
\hline Granulator & Electrical power $(\mathrm{kW})$ & 9.2 \\
\hline \multirow[t]{4}{*}{ Packaging } & Electrical Power $(\mathrm{kW})$ & 11 \\
\hline & $\begin{array}{l}\text { Time taken for packaging } \\
\text { (h) }\end{array}$ & 7 \\
\hline & Number of persons involved & 4 \\
\hline & Temp. of surrounding (K) & 298 \\
\hline
\end{tabular}

The useful work input into the system can be expressed by [15]:

$$
W_{u}=\left(e_{2}-e_{1}\right)-T_{o} R_{s}
$$

Where $W_{u}$ is the useful work, $R_{s}$ the production of entropy and $T_{0}$ the ambient temperature. The exergy difference $\left(e_{2}-e_{1}\right)$ is defined in terms of each component exergy $E_{x}$ per unit mass and the mass flow rate $\dot{m}$. From Eqn. 8, it is obvious that the exergy change is a balance of useful work and the entropy production term, which can be regarded as work lost because of irreversibilities.

Table 1 present the operating parameters of the factory while Table presents the parameters for evaluating the energy and exergy analysis of breakfast cereal production.

\section{RESULTS AND DISCUSSION}

\subsection{Energy Consumption of the System}

The energy consumption pattern for each unit operation is shown in Table 3. The energy consumption in intake operation was estimated as $0.11 \mathrm{MJ}$ for manual operation and this constitutes $0.01 \%$ of the total energy input. The average energy intensity for the intake operation was estimated as $0.004 \mathrm{MJ} /$ ton. The energy consumption in the cleaning operation was estimated as $10.4 \mathrm{MJ}$ with an average energy intensity of $0.42 \mathrm{MJ} /$ ton.

The total energy consumption for the milling operation where the cleaned grain is being grinded with the help of two roller mills was estimated as $383.04 \mathrm{MJ}$ as shown in Table 3, from which the proportion of electrical energy is $50.15 \%$. As it can be seen Roller mill 1 has the highest electrical input in this unit operation followed by Machine 1 and 2 respectively. The average energy intensity for the milling operation was estimated as $15.32 \mathrm{MJ} /$ ton. It is obvious that the milling operation has the highest average energy intensity in the production process.

The mixing operation which consists of the dry mixing and the wet mixing of the flour takes place here, other ingredients are added for the final processing of breakfast cereal. The energy input was estimated at 14.26 MJ (1.87\%) which was largely from the electrical energy process. The average energy intensity for the milling operation was estimated as $0.57 \mathrm{MJ} /$ ton.

The energy consumption in the roller dryer section of the mixing was estimated as $126.72 \mathrm{MJ}(16.59 \%)$ with an average energy intensity of $5.07 \mathrm{MJ} /$ ton. The utility energy being utilized for this process is steam from the boiler with a mass steam requirement of $200 \mathrm{l} / \mathrm{h}$ which 
is being consumed by the roller dryer at an operating pressure of 13.8 bar with $30,960 \mathrm{MJ}$ of thermal energy being produced by the boiler. The electrical energy is obtained directly from the tri-generating set with power ratings of $7.6 \mathrm{MW}$ at a load of $60-75 \%$. Finally, the packaging operation energy input was estimated as 229.72 MJ from which the proportion of manual energy is $0.99 \%$ and electrical energy input is $29.33 \%$, with an average energy intensity of $9.19 \mathrm{MJ} /$ tons. During operating hours of the plant, about 80,960 MJ of thermal energy is being produced by the generating set. The total energy requirement required to produce $25,000 \mathrm{~kg}$ of breakfast cereal was estimated at 31,723.85 MJ. The average energy intensity of the production process was found to be $1268.95 \mathrm{MJ} /$ ton. The proportion of the manual, electric and thermal energy in the total energy consumption is $0.02 \%, 2.3 \%$ and $97.59 \%$, respectively. The high thermal energy consumption depicts that the high level of steam usage in the Roller mill's drying unit. In contrast, lower trends have been reported for other food processing industries [33].

\subsection{Energy Expenditure of the Plant}

A total of 12 hours is required to process a batch of 30 ton of maize into $25,000 \mathrm{~kg}$ of maize flour. For this, electricity supply from the power generating set was used for the entire production process as the company is not connected to the national grid due to its erratic nature. The average rate of fuel consumption by the dual fuel generating set for diesel was $450 \mathrm{~kg} / \mathrm{h}$ while for an average gas consumption, it is $523 \mathrm{~kg} / \mathrm{h}$. For boiler (gas), the average consumption is $200 \mathrm{~kg} / \mathrm{h}$. The energy consumption pattern for the main group operations is shown in Table 4. The net energy input into the production units was estimated as 1,287.94 MJ with thermal, electrical and manual being 50.53\%, $48.87 \%$ and $0.60 \%$ of the energy input, respectively. The mixing operation consumed the highest energy with $655.10 \mathrm{MJ}$ (51.64\%), followed by the milling operation $383.04 \mathrm{MJ}$ (29.74\%), packaging operation with 229.32 MJ (17.81\%) while the intake operation accounts for the least energy with $0.11 \mathrm{MJ}$ (0.01\%).

Figure 3 shows the energy and material balance diagram of breakfast cereal production process. Here the stages involved in breakfast cereal is shown with the mass flow in $\mathrm{kg}$ of material being used with the corresponding energy consumed in MJ i.e. electrical, manual and thermal energy.

\subsection{Exergy Expenditure of the Plant}

The exergy analysis of the system gave insight to the inefficiencies and the opportunities for exergy loss minimization of each of the unit operations involved in the production of breakfast cereals. Conceptually the exergy calculations of the system were divided into process stream exergy and utility exergy.

Table 3: Overall energy consumption for breakfast cereal processing

\begin{tabular}{|c|c|c|c|c|}
\hline Operation & $\begin{array}{c}\text { Manual Energy Input } \\
\left(\mathrm{E}_{\mathrm{m}} / \mathrm{MJ}\right)\end{array}$ & $\begin{array}{c}\text { Electrical Energy Input } \\
\left(\mathrm{E}_{\mathrm{p}} / \mathrm{MJ}\right)\end{array}$ & $\begin{array}{c}\text { Thermal Energy Input } \\
\left(\mathrm{E}_{\mathrm{f}} / \mathrm{MJ}\right)\end{array}$ & $\begin{array}{c}\text { Total Energy Input } \\
\left(\mathrm{E}_{\mathrm{t}} \mathrm{MJ}\right)\end{array}$ \\
\hline INTAKE & & & & 0.11 \\
\hline CLEANING & 0.11 & & & \\
\hline $\mathrm{M} / \mathrm{C} 1$ & - & 5.2 & - & 5.2 \\
\hline $\mathrm{M} / \mathrm{C} 2$ & - & 5.2 & - & 5.2 \\
\hline \multicolumn{5}{|l|}{ MILLING } \\
\hline $\mathrm{M} / \mathrm{C} 1$ & - & 213.12 & - & 213.12 \\
\hline $\mathrm{M} / \mathrm{C} 2$ & - & 106.56 & - & 106.56 \\
\hline $\mathrm{M} / \mathrm{C} 3$ & - & 63.36 & - & 63.36 \\
\hline \multicolumn{5}{|l|}{ MIXING } \\
\hline Dry & - & 7.92 & - & 7.92 \\
\hline Wet & - & 6.34 & - & 6.34 \\
\hline Roller dryer & - & 126.72 & - & 126.72 \\
\hline PACKAGING & 7.56 & 221.76 & - & 229.32 \\
\hline BOILERS & - & - & 30,960 & 30,960 \\
\hline Total & 7.67 & 756.18 & 30,960 & $31,723.85$ \\
\hline
\end{tabular}


Table 4: Energy use data in the processing of breakfast cereal

\begin{tabular}{lcccccc}
\hline $\begin{array}{l}\text { Unit } \\
\text { operation }\end{array}$ & $\begin{array}{c}\text { Time taken } \\
(\mathrm{h})\end{array}$ & $\begin{array}{c}\text { Electrical } \\
\text { energy, } E_{P} \\
(\mathrm{MJ})\end{array}$ & $\begin{array}{c}\text { Thermal } \\
\text { energy, } E_{f} \\
(\mathrm{MJ})\end{array}$ & $\begin{array}{c}\text { Manual } \\
\text { energy, } E_{m} \\
(\mathrm{MJ})\end{array}$ & $\begin{array}{c}\text { Total energy, } E_{t} \\
(\mathrm{MJ})\end{array}$ & $\begin{array}{c}E_{t} / E_{o} \\
(\%)\end{array}$ \\
\hline Intake & 0.42 & - & - & 0.11 & 0.11 & 0.01 \\
Cleaning & 3 & 10.37 & - & - & 10.37 & 0.80 \\
Milling & 8 & 383.04 & - & - & 383.04 & 29.74 \\
Mixing & 3.35 & 14.26 & 650.84 & - & 665.10 & 51.64 \\
Packaging & 7 & 221.76 & - & 7.56 & 229.32 & 17.81 \\
Total & 21.80 & 629.43 & 650.84 & 7.67 & $1,287.94$ & 100.00 \\
Total & & 48.87 & 50.53 & 0.60 & 100.00 & - \\
\hline
\end{tabular}

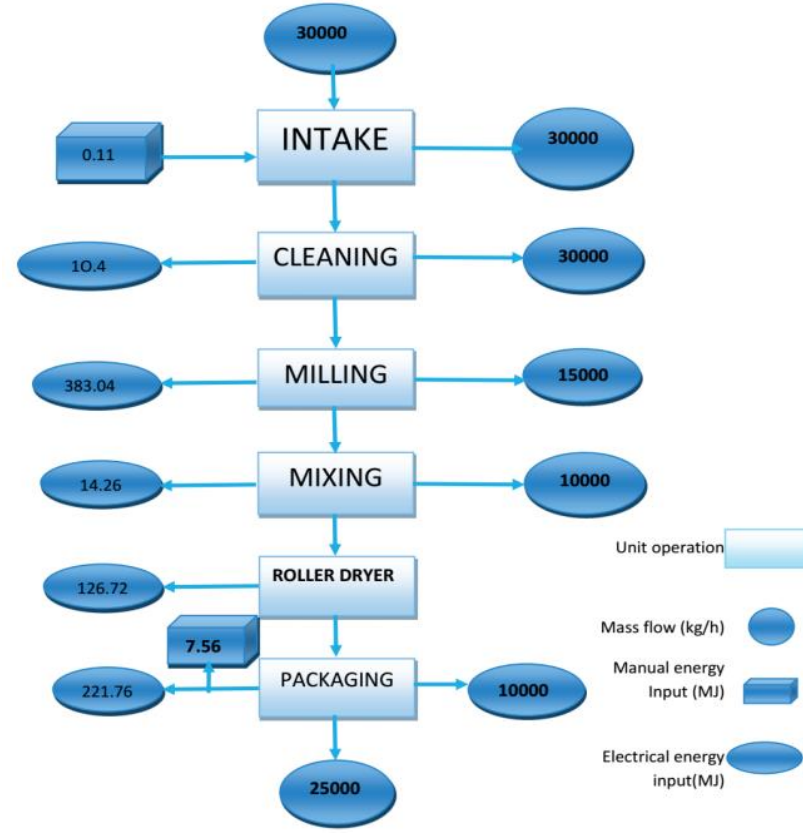

Fig 3: Energy and material balance diagram of breakfast cereal production operations.

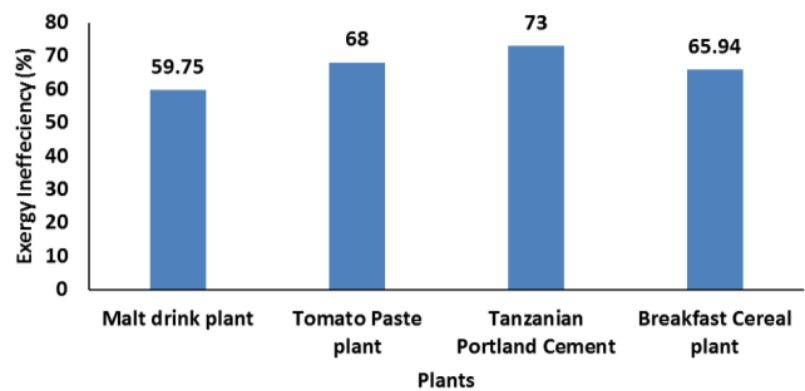

Fig 4: Exergy inefficiency of different plants

Table 5 shows the exergy change in the process stream, useful work, steam exergy (utilities), entropy generated and the inefficiency associated with each unit operation for the five group operations. The change in the exergy was only associated with operations where there was change in the inlet and outlet temperatures of the product. This can be seen to occur only in the wet mixer where hot water comes in and roller dryer unit where steam heats the drum and air to dry. Consequently, no exergy change was

Nigerian Journal of Technology, attributed to each of the unit operations in the intake, cleaning, dry mixing and the packaging operations because these operations take place without any appreciable change in temperature between the inlet and outlet of the processes.

Of the five group operations, the highest entropy was generated in the roller dryer where steam heated the drum followed by the wet mixer with respective values of 184,960 MJ and 75,002.07 MJ. The corresponding overall inefficiency of the roller dryer (air), roller dryer (steam) and wet mixer operation were $0.21 \%, 65.94 \%$ and $27.40 \%$, respectively. The losses in the roller dryer operation were due to irreversibility within the system as a result of high temperature difference between the inlet and the outlet stream of both the steam and the air. The result also revealed that the heating and cooling processes were inefficient. This is always the case for exergy calculations and is due to the fact that the exergy value of heat is often much lower than its energy value, particularly at temperatures close to reference temperature [27].

The high destruction of exergy implies that the energy has lost some of its ability to produce work resulting in reduction in its quality. Although direct comparison of the results of this work is not possible because of lack of reports on similar processes, but the present results show good trend with the results of some previous related works. For example, the $65.94 \%$ inefficiency in the roller dryer compared well with the $68 \%$ inefficiency in the evaporator unit of a tomato paste production plant [30], malt drink plant with $59.75 \%$ [27] and the 73\% inefficiency of the pre-heater unit of the Tanzanian Portland Cement Company [31] judging from the fact that the percentage rating of the inefficiency is a relative value. These two plants consist of many units where the contributions of utilities exergy change are significantly high. Figure 4 shows the exergy inefficiency of different plants compared to breakfast cereal. 
Table 5: Exergy balance in breakfast cereal production

\begin{tabular}{lcccccc}
\hline Unit operation & $\begin{array}{c}\text { Change in } \\
\text { exergy (MJ) }\end{array}$ & $\begin{array}{c}\text { Useful } \\
\text { work } \\
(\mathrm{MJ})\end{array}$ & $\begin{array}{c}\text { Change in } \\
\text { utility exergy } \\
(\mathrm{MJ})\end{array}$ & $\begin{array}{c}\text { Entropy } \\
\text { production } \\
(\mathrm{MJ})\end{array}$ & $\begin{array}{c}\text { Group operation } \\
\text { inefficiency (\%) }\end{array}$ & $\begin{array}{c}\text { Overall system } \\
\text { inefficiency (\%) }\end{array}$ \\
\hline Wet Mixer & - & 6.34 & - & $75,002.07$ & 28.78 & 27.4 \\
Roller dryer & - & 126.72 & - & 635.25 & 0.24 & 0.21 \\
(Air) & & & & & & \\
Steam & $2,052.57$ & 229.32 & $68,247.17$ & 184,960 & 70.98 & 65.94 \\
Total & $2,052.57$ & 362.44 & $68,247.17$ & $260,597.32$ & 100 & 93.55 \\
\hline
\end{tabular}

\section{CONCLUSIONS}

The energy and exergy analysis of the breakfast cereal production reveal that the energy intensity required to process a 30 ton maize into flour is $11.27 \mathrm{MJ} / \mathrm{kg}$, with thermal energy being the most energy- intensive process with $650.84 \mathrm{MJ}$ of energy required for production closely followed by electrical energy with $629.43 \mathrm{MJ}$ and manual energy being the least energy consuming process with $7.67 \mathrm{MJ}$. This is as a result of the automation level of the factory. For the intake, milling, mixing, roller dryer and packaging, the energy consumed was $0.11,10.40,383.04,14.62,126.72$ and 229.32 MJ, respectively.

The exergy analysis showed that the roller dryer accounts for the major loss in the process with an inefficiency of $65.94 \%$, with the wet mixer also accounting for $27.40 \%$ of the inefficiency (total inefficiency of the plant being $93.55 \%$ ). The change in utility exergy was $68,247.17 \mathrm{MJ}$ in the roller dryer, with a total useful work being 156, $746.20 \mathrm{MJ}$ and the entropy production for the wet mixer, roller dryer (air), roller dryer (steam) was 75002.07, 635.25, 184,960 MJ, respectively.

\section{REFERENCES}

[1]. Bamgboye A. I. and Jekayinfa S. 0. "Trends and Effective Use of Energy Input in the Palm Kernel Oil Mills". Tropicultura, Vol. 25, Number 1, , pp. 7112007

[2]. Osueke C. 0 and Ezugwu C. A. K. "Study of Nigeria Energy Resources and Its Consumption" International Journal of Scientific \& Engineering Research. Vol. 2, , pp. 1-8, 2011.

[3]. Waheed M. A., Jekayinfa S. O., Ojediranb J. O. and Imeokparia 0. E. "Energetic analysis of fruit juice processing operations in Nigeria" Energy, Vol. 33, pp. 35-45, 2008.
[4]. Jaja C. Y. "Recent Trends and Patterns of Gasoline Consumption in Nigeria" Africa Development. Vol. 35, Number 3, pp. 159 - 177, 2010.

[5]. Atuonwu J. C., Jin X., Van Straten G., Antonius H. C. and Van Boxtel J. B. "Reducing energy consumption in food drying: Opportunities in desiccant adsorption and other dehumidification strategies" Procedia Food Science Vol. 1, pp. 17991805, 2011.

[6]. Akinoso R., Lawal I. A. and Aremu A.K. "Energy requirements of size reduction of some selected cereals using attrition mill" International Food Research Journal, Vol. 20, Number 3, pp. 12051209, 2013.

[7]. Danciu C. and Danciu I. "Energy saving opportunities related to the size reduction for the first break, in the wheat milling, with a new designed micro mill. Selected topics in energy, environment, sustainable development and Landscaping"

https://www.google.com.ng/url?sa =t\&rct=j\&q= \&esrc $=s \&$ source $=$ web $\& c d=8 \& c a d=r j a \& v e d=0 \mathrm{CH}$ wQFjAH\&url=http\%3A\%2F\%2Fwww.fia.usv.ro\% 2Favizier\%2Fbiotehnologii\%2Fabstracte\%2Fa3.p df\&ei=NnegUdOOMYTK0AXQ_YGQAw\&usg $=\mathrm{AFQj}$ CNEjoylW0ajSavZw4L5UUrtj7uU2GA\&bvm =bv.47 008514,d.d2k,_ 2010 Accessed on August 12, 2015

[8]. Gwirtz J. "Electrical energy savings in flour milling" http://www.flourmillmachine.com/Electrical-energy-savings-in-flourmilling.html 2008. Accessed on May 3, 2015.

[9]. Dziki D. and Laskowski J. "Influence of selected factors on wheat grinding energy requirements" Teka Kom. Mot. Energy. Roln. Vol. 5, pp. 56-64 , 2005.

[10]. Bitra V. S. P., Womaca A. R., Igathinathane C., Miu P. I., Yang Y. T., Smith D. R., Chevanan N. and Sokhansanj S. "Direct measures of mechanical energy for knife mill size reduction of switchgrass, wheat straw, and corn stover" Bioresource Technology, Vol. 100, pp. 6578-6585, 2009. 
[11]. Bitra V. S. P., Womaca A. R., Chevanan N., Miu P. I., C. Igathinathane C., Sokhansanj S. and Smith D. R. "Direct mechanical energy measures of hammer mill comminution of switchgrass, wheat straw, and corn stover and analysis of their particle size distributions" Powder Technology, Vol. 193, pp. 32-45, 2009.

[12]. Sulaiman, M. A., Waheed, M. A., Adesope, W. A. and Noike, A." Techno-Economic Investigation of Different Alternatives of Improving Simple Gas Turbine Integration Options" Nigerian Journal of Technology, Vol. 36, No. 3, July 2017, pp. 849 - 857.

[13]. Dincer Ibrahim and Cengel Yunus A. "Energy, Entropy and Exergy Concepts and Their Roles in Thermal Engineering" Entropy, Vol. 3, pp: 116149, 2001

[14]. Siahaya Y.. Energy, Exergy and Thermoeconomic Analysis of Lahendong Binary - Cycle Geothermal Power Plant at North Sulawesi Indonesia. In Proc. 7th International Conference on Fluid and Thermal Energy Conversion. Zhengzhou, China, 115, 2011.

[15]. Ameri M., Ahmadi P. and Hamidi A. "Energy, exergy and exergoeconomic analysis of a steam power plant: A case study" International Journal of Energy Research, Vol. 33, pp. 499-512, 2009.

[16]. Jekanyinfa S. O. and Bamgboye A. I. "Development of equations for estimating energy requirements in palm-kernel oil processing operations" Journal of Food Engineering, Vol. 79, Number 1, 2007, pp. 322-329

[17]. Patzek T. W. "A First-Law Thermodynamic Analysis of the Corn-Ethanol Cycle" Natural Resources Research, Vol. 15, Number 4, pp. 255270, 2006.

[18]. Therkelsen P., Masanet E. and Worrell E. "Energy efficiency opportunities in the U.S. commercial baking industry" Journal of Food Engineering, Vol. 130, pp. 14-22, 2014.

[19]. Wojdalski J, Grochowicz J, Drozdz B, Bartoszewska K, Zdanowska P, Kupczyk A, Ekielski A, Florczak I, Hasny A, Wojcik G. "Energy efficiency of a confectionery plant - Case study". Journal of Food Engineering, Vol. 146, pp. 182-191, 2015.

[20]. Akinoso R., Olapade A. A. and Akande A. A. "Estimation of Energy Requirements in Cowpea Flour Production in Nigeria" Focusing on Modern Food Industry, Vol. 2, Number 2, pp. 86-90, 2013.

[21]. Ryan B. and Douglas G. T.. Minnesota Agricultural Energy Use and the Incidence of a Carbon Tax. Institute for Local Self Reliance, Minneapolis,
Minnesota. Bioenergy 1998 proceedings, 1:56-65, 1998.

[22]. Abubakar M. and Umar B.. Comparison of Energy Use Patterns in Maiduguri and Yobe Flour Mills, Nigeria. Agricultural Engineering International: the CIGR E journal. Manuscript EE 06 004, Vol. VIII, 2006

[23]. Earl G. Hammond, Lawrence A. Johnson, Caiping Su, Tong Wang, and Pamela J. White Chapter 13Soybean Oil. Bailey's Industrial Oil and Fat Products, Sixth Edition, Six Volume Set. Edited by Fereidoon Shahidi. John Wiley \& Sons, Inc. 2005.

[24]. Farroni A.E. and Buera M. Cornflake Production Process: State Diagram and Water Mobility Characteristics. Food and Bioprocess Technology, Vol. 7, Number10, pp. 2902-2911, 2014.

[25]. Roos Y.H. "Thermal analysis, state transitions and food quality" Journal of Thermal Analysis and Calorimetry, Vol. 71, Number 1, pp. 197-203, 2003.

[26]. Rawitcher M. and Mayer J. "Energy requirements and breakfast cereals" Food Policy, Vol. 6, Number 1, pp. 27-32

[27]. Fadare, D. A., Nkpubre, D. O., Oni, A. O., Falana, A., Waheed, M. A and Bamiro, 0. A. "Energy and Exergy Analyses of Malt Drink Production in Nigeria" Energy Vol. 35, Number 12, pp. 53365346, 2010.

[28]. Odigboh E. U. "Machines for crop production" In: Stout B. A, editor. CIGR hand-book of agricultural engineering. American Society of Agricultural Engineers, 1998.

[29]. Oyedepo S. O. and Aremu T. O. "Energy Audit of Manufacturing and Processing Industries in Nigeria: A case Study of Food Processing Industry and Bottling Company" American Journal of Energy Research, Volume 1, Number 3, pp. 36-44, 2013.

[30]. Singh R. P. "Energy accounting in food process operations" Food Technology, Vol. 32, Number 4, pp. 40-6. 1978

[31]. Rotstein E. "Exergy analysis: a diagnosis and heat integration tool". In: Singh RP, editor. Energy in Food Processing. Elsevier, 1986.

[32]. Van Schijndel P.P.A.J., Van Kasteren J. M. N. and Janssen F.J.J.G. "Exergy analysis: a tool for sustainable technology in engineering education" In: Proceedings of ENTRE'E 1998 (Environmental Training in Engineering Education), innovation strategies for economy and environment, Deventer, the Netherlands. 4-6 November, 1998. 